\title{
CHECKING OF THE METHODICAL SYSTEM EFFICIENCY OF FITNESS TECHNOLOGIES APPLICATION IN STUDENTS' PHYSICAL EDUCATION
}

DOI: 10.36740/WLek202002125

\author{
Valeriy 0. Zhamardiy ${ }^{1}$, Olena M. Shkola², Ivan M. Okhrimenko ${ }^{3}$, Oksana G. Strelchenko ${ }^{3}$, Alla I. Aloshyna ${ }^{4}$, \\ Fyodor H. Opanasiuk ${ }^{5}$, Grygoriy P. Gribann ${ }^{6}$, Vitalii P. Yahodzinskyi ${ }^{7}$, Oleksandr M. Mozolev ${ }^{8}$, Kostiantyn V. Prontenko ${ }^{9}$ \\ 'UKRAINIAN MEDICAL STOMATOLOGICAL ACADEMY, POLTAVA, UKRAINE \\ 2MUNICIPAL ESTABLISHMENT "KHARKIV HUMANITARIAN PEDAGOGICAL ACADEMY" OF KHARKIV REGIONAL COUNCIL, KHARKIV, UKRAINE \\ ${ }^{3}$ NATIONAL ACADEMY OF INTERNAL AFFAIRS, KYIV, UKRAINE \\ ¿LESYA UKRAINKA EASTERN EUROPEAN NATIONAL UNIVERSITY, LUTSK, UKRAINE \\ 5ZHYTOMYR NATIONAL AGROECOLOGICAL UNIVERSITY, ZHYTOMYR, UKRAINE \\ ${ }^{6}$ ZHYTOMYR IVAN FRANKO STATE UNIVERSITY, ZHYTOMYR, UKRAINE \\ 'ODESA MILITARY ACADEMY, ODESA, UKRAINE \\ ${ }^{8}$ KHMELNYTSKYI HUMANITARIAN-PEDAGOGICAL ACADEMY, KHMELNYTSKYI, UKRAINE \\ ${ }^{9}$ S. P. KOROLIOV ZHYTOMYR MILITARY INSTITUTE, ZHYTOMYR, UKRAINE
}

\begin{abstract}
The aim is to carry out a comparative analysis of the effectiveness of the traditional system of physical education of students in higher pedagogical education establishments and authors'methodical system of fitness technologies application.

Materials and methods: Two hundred thirty two students of Zhytomyr Ivan Franko State University ( $n=232 ; 88$ males and 144 females) aged from 18 to 20 years old took part in the research. Two experimental groups (EG, 47 males and 71 females) and two control groups (CG, 41 males and 73 females) were formed. Students were offered the following modern types of fitness technologies: power fitness, aerobics, Pilates, swimming, yoga, tae-bo.

Results: The positive effect of the authors' methodical system of fitness technologies application in comparison with the traditional system of physical education has been achieved - according to all the criteria of the research, the indicators of EG students (both males and females) are significantly better than those of the students from CG. Conclusions: It proves the necessity for the modern fitness technologies application in the educational process of physical education in higher education pedagogical establishments with the aim of improving the state of physical fitness, health of students and increasing their motivation for independent physical exercises and healthy lifestyles in the future.
\end{abstract}

KEY WORDS: physical education, health, fitness technology, student

Wiad Lek. 2020;73(2):332-341

\section{INTRODUCTION}

A natural result of finding effective ways to improve the educational process of physical education in higher pedagogical education establishments is the introduction and application of modern fitness technologies [1,2,3]. A wide range of their trends and types allows not only to update the content of physical education, but also to motivate students to a healthy lifestyle $[4,5,6]$. Fitness technologies enable the complex use of modern fitness programs in the process of training classes with students depending on their age characteristics, state of health, level of physical training, forming motivational priorities that promote the development of positive motivation for physical education and independent health activities $[7,8,9]$. Retrospective analysis of scientific data in pedagogy, theory and methodology of physical education $[3,10,11,12]$ indicates a large amount of theoretical and experimental material for the application of different types and trends of fitness technology in the educational process of physical education. It should be noted that the concepts of fitness technology are constantly changing depending on the development tendencies in the fitness industry $[13,14,15]$.

Scientists $[1,5,12,16,17,18]$ study various aspects of the fitness technologies application in higher pedagogical education establishments, in particular, the use of innovative means and forms of organization of classes, the formation of students' recreational culture, training and professional development of specialists in physical recreation and fitness, conducting the control of physical training, students' physical health. Scientists consider fitness technology as an important factor in personal development, the improvement of youth's health through the rational use of motor activity together with other health-improving factors [19, $20,21]$. The leading role of the modern fitness technology 
application lies in solving health-improving, recreational, preventive and recovery tasks using various types of motor activity $[8,16,18,22,23,24]$.

\section{THE AIM}

The aim of the study is to carry out a comparative analysis of the effectiveness of the traditional system of physical education of students in higher pedagogical education establishments and authors' methodical system of fitness technologies application.

The objectives:

1) to substantiate theoretically the indicators of students' physical activity with implementation of methodical system of fitness technologies application;

2) to study the dynamics of the theoretical knowledge growth of physical education and sports;

3) to study the dynamics of the motivation formation among students during the period of the pedagogical experiment;

4) to study the dynamics of physical fitness for students who were trained according to the traditional system of physical education and students who were trained according to the authors' methodical system of fitness technologies application;

5) to study the dynamics of students' health as a result of their self-esteem state of health.

\section{MATERIALS AND METHODS}

Two hundred thirty two students of the Zhytomyr Ivan Franko State University (88 males and 144 females) from different faculties (historical, psychological and pedagogical, physical and mathematical, philology and journalism) aged from 18 to 20 years old took part in the research. Two experimental groups (EG, 47 males and 71 females) and two control groups (CG, 41 males and 73 females) were formed. Formation of groups was carried out at the beginning of the study (in the first semester) from the students of the main medical department on the basis of the questionnaire results to find out the interests, motives and needs of students for training according to the traditional system of physical education or additional classes of fitness technologies. The indicators of physical fitness and health of students from EG and CG at the beginning of the experiment were reliably the same $(\mathrm{p}>0.05)$.

The experiment was organized in 2016-2018 during the training of students in the $1^{\text {st }}$ and $2^{\text {nd }}$ years of study. The conducting of classes in EG and CG was carried out by teachers and trainers of the Department of Physical Education and Sport Improvement. Students were offered the following modern types of fitness technologies: power fitness, aerobics, Pilates, swimming, yoga, and tae-bo for additional classes with the use of fitness technology.

Testing of physical fitness was carried out according to the following exercises ( 9 exercises for males and females). They characterize the level of development of students' various physical qualities of different genders: running at $100 \mathrm{~m}$ (speed qualities) - males, females; pull-ups on the crossbar (power qualities) - males; bending and unbending of arms in lying support (power qualities) males, females; running at $3000 \mathrm{~m}$ (endurance) - males; running at $2000 \mathrm{~m}$ (endurance) - females; standing long jump (speed-power qualities) - males, females; sit-ups for $1 \mathrm{~min}$ (power qualities) - males, females; shuttle running $4 \times 9 \mathrm{~m}$ (agility) - males, females; forward reach (flexibility) - males, females; swimming with free style on a range (special endurance) - males, females; hanging on bent hands (static endurance) - females.

To investigate the level and dynamics of health of students of EG and CG during the experiment, we used the method of «Health self-esteem», proposed by Professor V. P. Voytenko (1991). The research was conducted by the method of questioning. Students were asked a questionnaire containing 27 questions regarding their health status, such as: are you worried about a headache; are you concerned about heart pain; do you think your eyesight is getting worse; whether you are concerned about memory loss; whether you have to give up some dishes; do you think your performance has deteriorated and so on. The first 26 questions include "yes" or "no", and the last ("How do you rate your health?") - "good", "satisfactory", "bad", "very bad". 1-26 questions were evaluated as follows: 1 point was scored for each answer "yes", 0 point - for the answer "no". The total corresponds to the quantitative self-assessment of health. If the answer to the last question is "bad" or "very bad", 1 point is added. The results of the questionnaire were evaluated as follows: if a student scored $0-3$ points, his / her health level was rated as perfect; 4-7 - good; 8-13 average; $14-20$ - satisfactory; $21-27$ - unsatisfactory.

The effectiveness of the developed methodical system of fitness technologies application in the educational process on physical education of students in higher pedagogical education establishments was estimated according to the following indicators:

- the volume of physical activity;

- the general level of theoretical training according to the curriculum on physical education, the availability of special knowledge and skills in fitness technology application during independent trainings;

- the dynamics of motivation for physical exercises and sports in general and, in particular, to the fitness technologies application;

- the level of general physical fitness and development of certain physical qualities;

- self-esteem state of health.

The research involved the use of theoretical and empirical methods. The theoretical methods were the study and analysis of scientific, pedagogical, methodological manuals, educational programs, curriculum and normative documents; synthesis; generalization, comparison and juxtaposition. The empirical methods were pedagogical observation, questionnaires, testing, pedagogical experiment, methods of mathematical statistics. The pedagogical experiment was aimed at revealing the advantages of experimental methodical system of fitness technologies 
Table 1. Weekly volumes of physical activity of students after implementation of methodical system of fitness technologies application in the educational process on physical education ( $\mathrm{n}=232$, in hours, $\min$ )

\begin{tabular}{|c|c|c|c|c|c|c|c|c|}
\hline \multirow[t]{2}{*}{ Types of physical activities } & \multirow[t]{2}{*}{ Groups } & \multirow[t]{2}{*}{ Gender } & \multirow{2}{*}{$\begin{array}{c}\begin{array}{c}\text { Initial } \\
\text { data }\end{array} \\
\text { Time }\end{array}$} & \multicolumn{2}{|c|}{$\begin{array}{l}\text { The end } \\
\text { 2016-2017 }\end{array}$} & \multicolumn{2}{|c|}{$\begin{array}{l}\text { The end } \\
\text { 2017-2018 }\end{array}$} & \multirow{2}{*}{$\begin{array}{c}\text { Growth } \\
\text { Time }\end{array}$} \\
\hline & & & & Time & $\%$ & Time & $\%$ & \\
\hline \multirow{4}{*}{$\begin{array}{l}\text { Classes according to the } \\
\text { schedule }\end{array}$} & \multirow{2}{*}{ EG } & males & $3: 00$ & $2: 46$ & 92.2 & $2: 42$ & 90.0 & $-0: 18$ \\
\hline & & females & $3: 00$ & $2: 52$ & 95.6 & $2: 47$ & 92.8 & $-0: 13$ \\
\hline & \multirow{2}{*}{ CG } & males & $3: 00$ & $2: 22$ & 78.9 & $1: 57$ & 65.0 & $-1: 03$ \\
\hline & & females & $3: 00$ & $2: 18$ & 76.7 & $2: 23$ & 79.4 & $-0: 37$ \\
\hline \multirow{4}{*}{$\begin{array}{l}\text { Fitness technologies classes in } \\
\text { section }\end{array}$} & \multirow{2}{*}{ EG } & males & $1: 30$ & $1: 24$ & 93.3 & $1: 27$ & 96.7 & $-0: 03$ \\
\hline & & females & $1: 30$ & $1: 26$ & 95.6 & $1: 26$ & 95.6 & $-0: 04$ \\
\hline & \multirow{2}{*}{ CG } & males & - & - & - & - & - & - \\
\hline & & females & - & - & - & - & - & - \\
\hline \multirow{4}{*}{$\begin{array}{c}\text { Additional classes on physical } \\
\text { education }\end{array}$} & \multirow{2}{*}{ EG } & males & - & - & - & - & - & - \\
\hline & & females & - & - & - & - & - & - \\
\hline & \multirow{2}{*}{ CG } & males & $1: 30$ & 1:03 & 70.0 & $0: 51$ & 56.7 & $-0: 39$ \\
\hline & & females & $1: 30$ & $1: 02$ & 68.9 & $0: 47$ & 52.2 & $-0: 43$ \\
\hline \multirow{4}{*}{ Independent classes in free time } & \multirow{2}{*}{ EG } & males & $1: 34$ & $3: 43$ & 237.2 & $4: 25$ & 281.9 & $2: 51$ \\
\hline & & females & 1:08 & $3: 36$ & 317.7 & $3: 58$ & 350.0 & $2: 50$ \\
\hline & \multirow{2}{*}{ CG } & males & 1:02 & $1: 37$ & 156.5 & 1:07 & 108.1 & 0:05 \\
\hline & & females & $0: 54$ & $1: 03$ & 116.7 & 1:01 & 113.0 & $0: 13$ \\
\hline \multirow{4}{*}{ Morning hygienic gymnastics } & \multirow{2}{*}{ EG } & males & $0: 31$ & $1: 34$ & 303.2 & $1: 42$ & 329.0 & 1:11 \\
\hline & & females & $0: 29$ & $1: 25$ & 293.1 & $1: 19$ & 272.4 & $0: 50$ \\
\hline & \multirow{2}{*}{ CG } & males & $0: 26$ & $0: 39$ & 150.0 & $0: 35$ & 134.6 & 0:09 \\
\hline & & females & $0: 24$ & $0: 33$ & 137.5 & $0: 39$ & 162.5 & $0: 15$ \\
\hline \multirow{4}{*}{$\begin{array}{l}\text { Participation in physical and } \\
\text { health-improving events }\end{array}$} & \multirow{2}{*}{ EG } & males & $0: 11$ & $1: 15$ & 618.8 & $1: 17$ & 700.0 & 1:06 \\
\hline & & females & 0:09 & $0: 33$ & 366.7 & $0: 51$ & 566.7 & $0: 42$ \\
\hline & \multirow{2}{*}{ CG } & males & $0: 13$ & $0: 27$ & 207.7 & $0: 41$ & 315.4 & $0: 28$ \\
\hline & & females & $0: 07$ & $0: 11$ & 157.1 & $0: 13$ & 185.7 & $0: 06$ \\
\hline \multirow{4}{*}{ Total } & \multirow{2}{*}{ EG } & males & $6: 46$ & $10: 42$ & 158.1 & $11: 33$ & 170.7 & $4: 47$ \\
\hline & & females & $6: 16$ & $9: 52$ & 157.5 & $10: 21$ & 162.5 & $4: 05$ \\
\hline & \multirow{2}{*}{ CG } & males & $6: 11$ & $6: 08$ & 99.2 & $5: 11$ & 83.8 & $-1: 00$ \\
\hline & & females & $5: 55$ & $5: 07$ & 86.5 & $5: 03$ & 85.4 & $-0: 52$ \\
\hline
\end{tabular}

application in the educational process of students' physical education in higher pedagogical education establishments. In the pedagogical experiment, in addition to the formation and upbringing of the students' personality through the use of fitness technologies, the comparative analysis was conducted to identify differences between the indicators of the physical education effectiveness of the students of control and experimental groups, as well as the significance of the studied indicators. In order to determine the authenticity of the difference between the indicators of students of EG and CG in the process of pedagogical experiment, Student's t-test was applied. The significance for all statistical tests was set at $\mathrm{p}<0.05$. All statistical analyses were performed with the SPSS software, version 21, adapted to medical and biological researches.
The research related to human use has been complied with all the relevant national regulations and institutional policies, and has followed the tenets of the World Medical Association Declaration of Helsinki - ethical principles for medical research involving human subjects. Informed consent has been obtained from all individuals included in this research.

\section{RESULTS}

In our research, fitness technology is a rational way of purposeful interaction of participants in the pedagogical process that is based on the types of motor activity aimed at obtaining the maximum possible health effect, the realization of students' need for health and careful attitude to 
Table 2. The dynamics of the students' theoretical knowledge growth after implementation of the methodical system of fitness technologies into the educational process of physical education ( $n=232, X \pm m$, in points)

\begin{tabular}{|c|c|c|c|c|c|c|c|}
\hline \multirow{2}{*}{$\begin{array}{l}\text { Estimation } \\
\text { indicators }\end{array}$} & \multirow{2}{*}{ Groups } & \multirow{2}{*}{ Gender } & \multicolumn{2}{|c|}{ Stages of the experiment } & \multirow{2}{*}{ Growth } & \multicolumn{2}{|c|}{ Difference reliability } \\
\hline & & & The beginning & The end & & $\mathbf{t}$ & $\mathbf{p}$ \\
\hline \multirow{4}{*}{$\begin{array}{l}\text { General theoretical } \\
\text { training }\end{array}$} & \multirow{2}{*}{ EG } & males & $2.13 \pm 0.11$ & $4.49 \pm 0.19$ & 2.36 & 3.89 & $<0.001$ \\
\hline & & females & $2.27 \pm 0.09$ & $4.64 \pm 0.21$ & 2.37 & 3.75 & $<0.001$ \\
\hline & \multirow{2}{*}{ CG } & males & $2.17 \pm 0.07$ & $3.09 \pm 0.16$ & 0.92 & 2.24 & $<0.05$ \\
\hline & & females & $2.41 \pm 0.13$ & $3.24 \pm 0.17$ & 0.83 & 1.67 & $<0.05$ \\
\hline \multirow{4}{*}{$\begin{array}{l}\text { Special knowledge } \\
\text { as for the fitness- } \\
\text { technology } \\
\text { application }\end{array}$} & \multirow{2}{*}{ EG } & males & $1.14 \pm 0.07$ & $4.61 \pm 0.20$ & 3.47 & 4.35 & $<0.001$ \\
\hline & & females & $1.73 \pm 0.09$ & $4.76 \pm 0.21$ & 3.03 & 3.96 & $<0.001$ \\
\hline & \multirow{2}{*}{ CG } & males & $1.42 \pm 0.06$ & $2.42 \pm 0.12$ & 1.00 & 2.18 & $<0.05$ \\
\hline & & females & $1.63 \pm 0.07$ & $2.69 \pm 0.13$ & 1.06 & 2.61 & $<0.01$ \\
\hline
\end{tabular}

Table 3. The dynamics of motivation formation in students during the period of pedagogical experiment ( $n=232$, in \%)

\begin{tabular}{|c|c|c|c|c|c|c|c|c|}
\hline \multirow{3}{*}{ Motivation level } & \multicolumn{4}{|c|}{ Experimental groups } & \multicolumn{4}{|c|}{ Control groups } \\
\hline & \multicolumn{2}{|c|}{$\begin{array}{l}\text { At the beginning of } \\
\text { the experiment }\end{array}$} & \multicolumn{2}{|c|}{$\begin{array}{l}\text { At the end of the } \\
\text { experiment }\end{array}$} & \multicolumn{2}{|c|}{$\begin{array}{c}\text { At the beginning of the } \\
\text { experiment }\end{array}$} & \multicolumn{2}{|c|}{$\begin{array}{l}\text { At the end of the } \\
\text { experiment }\end{array}$} \\
\hline & $\mathbf{n}$ & $\%$ & $\mathbf{n}$ & $\%$ & $\mathbf{n}$ & $\%$ & $\mathbf{n}$ & $\%$ \\
\hline \multicolumn{9}{|c|}{ Males $(E G=47, C G=41)$} \\
\hline High & 2 & 4.3 & 18 & 38.3 & 3 & 7.3 & 5 & 12.2 \\
\hline Average & 8 & 17.1 & 23 & 48.9 & 10 & 24.4 & 13 & 31.7 \\
\hline Low & 37 & 78.7 & 6 & 12.8 & 28 & 68.3 & 23 & 56.1 \\
\hline \multicolumn{9}{|c|}{ Females $(E G=71, C G=73)$} \\
\hline High & 4 & 5.6 & 21 & 29.6 & 3 & 4.1 & 4 & 5.5 \\
\hline Average & 19 & 26.8 & 34 & 47.9 & 24 & 32.9 & 29 & 39.7 \\
\hline Low & 48 & 67.6 & 16 & 22.5 & 46 & 63.1 & 40 & 54.8 \\
\hline
\end{tabular}

it through conscious regulation of physical activity. Fitness technology is a system of constructive influence on the students' body by means of specially selected, dosed exercises that provide solutions to important health problems. They allow to reflect the biological (state of health, physical fitness, motor activity), mental (motives, interests), social (healthy lifestyle) needs of students for physical education classes. Fitness technology is a generalized, integrative concept of the entire modern range of fitness services that are determined by the motor activity of the health-improving orientation and includes a large number of new trends and types of fitness programs that are different in terms of the content and nature of the application. In the educational process on physical education, fitness technology is applied through fitness programs as forms of motor activity, specially organized in group or individual (personal) classes. The most popular fitness programs during the physical education classes were based on the use of types of motor activity of the aerobic direction, fitness programs based on types of motor activity of the power orientation, fitness program of dance orientation, fitness program with elements of martial arts, fitness program in water environment, fitness program of mentally regulation orientation. The most popular types of fitness technologies among the students of higher pedagogical education es- tablishments were the following: power fitness, aerobics, Pilates, swimming, yoga, tae-bo.

The analysis of the results of experimental work showed that the methodical system of fitness technologies application in the educational process on physical education of students in higher pedagogical education establishments contributes to the education of a positive attitude of students to the means of physical culture and sports, improves motor and physical activity of students. According to scientists [6, $16,25,26,27]$, motor activity consists of movements that are one of the necessary conditions of life. It improves work capability, health, provides versatile harmonious development, functioning of the cardiovascular, respiratory, hormonal and other systems of the body, activates the neuromuscular apparatus and mechanisms for transferring the reflexes from the muscles to the internal organs. Physical activity always acts as one of the most effective preconditions for a healthy lifestyle and the formation of physical qualities. Therefore, the physical activity of a person as a final result is aimed at changing the state of his body, to acquire a new level of development of physical qualities. It cannot be achieved by any other means than training $[8,20,28]$.

Experimental researches have confirmed that the traditional system of physical education can't significantly improve the physical activity of students; it does not provide 
qualitative changes in the structure of the budget of their time. Comparison of the time the students from control and experimental groups spent on training and independent exercises in fitness technologies, doing sport, participation in sport and mass, physical and health-improving events, doing of morning hygienic gymnastics and other types of motor activity indicates a large gap between the groups (Table 1).

Students from experimental groups miss the physical training classes less, attend classes in sections and groups on fitness technologies, are involved in morning hygienic gymnastics and participate in sports and mass, physical and health-improving events. A comparative analysis of the time spent on physical activity showed significant differences between the experimental and control groups.

Males and females in the experimental group improved their indicators compared with initial data, respectively, for $4 \mathrm{~h} 47 \mathrm{~min}$ and $4 \mathrm{~h} 5 \mathrm{~min}$, control group students lowered their indicators below the initial level (males for 1 hour and females for 52 minutes). The decrease in the level of physical activity in control groups was due to the missing of training and additional classes.

Theoretical knowledge of physical education is the basis for activating the consciousness of students and determining the level of their needs for motor activity. Mastering of theoretical knowledge stimulates the students to analyze the facts, their generalization and conclusions, activates their ability to retrospectively search for information, its systematization, analysis and synthesis, accumulation of individual informational experience. Mastering the theoretical section involves students to learn the values of physical culture, develops and forms the cultural potential of the students' personality, expands his/her outlook, spreads his/her outlook, promotes the formation of an active life position $[15,23,29]$.

Implementation of the methodical system of fitness technologies application significantly influenced on mastering theoretical information about physical culture and sport intensified the interest of students to study the fitness technologies and developing the skills for using them during independent exercises in the future (Table 2). The level of theoretical knowledge of students from EG is significantly better than in the CG.

The conducted pedagogical experiment showed that the initial level of theoretical knowledge according to all the studied parameters in both EG and CG in males and females is quite low (1.14-2.27 points) and is evaluated as unsatisfactory. Purposeful work on the formation of theoretical knowledge of physical education brought positive results in EG. Indicators of theoretical training in the EG have substantially increased during the pedagogical molding experiment. At the end of the research, the level of theoretical training is evaluated as good in the EG, and it is satisfactory and unsatisfactory in CG. Indicators of EG during the period of the pedagogical experiment have a significant difference $(\mathrm{p}<0.001)$.

At the same time, the analysis of the results showed that there was also a significant improvement in the indicators in CG $(\mathrm{p}<0.05)$. But in the EG, where the methodical system of fitness technologies application was introduced, the growth indicators of theoretical knowledge both in males (2.36 and 3.47 points) and females ( 2.37 and 3.03 points) have a significantly higher growth than in CG (0.92 and 1.00 points and 0.83 and 1.06 points respectively).

The motivation of students of experimental and control groups for physical exercise and sports, in particular, fitness technologies at the beginning and at the end of the study was studied to activate the educational process on physical education and implementation of the methodical system of fitness technologies application with the help of questionnaires.

The person-orientation of students to the choice of motor activity in the process of training with modern fitness technologies cannot be determined only on the basis of their needs and interests. According to scientists $[4,7$, 9], the same needs and interests that become the motive of activity can be realized by a person in order to achieve different values, one and the same need can have different ways of satisfaction. The concept of interest reflects the most appropriate way to meet their needs for the students. The concept of interest as if develops the concept of need in the direction of satisfying a certain need. In this case, the interest in fitness technology exercises on the contrary to the need, the orientation of the students' personality to search and learn new means of physical improvement. At the same time, it is very important to know and take into account the students' value orientations.

In order to achieve the purpose of methodical system of fitness technologies application in the educational process of physical education, students must get a set of motives and interests for this type of activity, develop the need for motor activity, and create favorable conditions for this. Achievement of the purpose during fitness technology training is possible only if students intend to realize their most significant needs in the person-oriented choice of motor activity means. Only under such conditions the formation of a valuable attitude to fitness technology will be done. An important condition for formulating the purpose is its fullness and a clear orientation of the student for the need to get certain knowledge, skills and abilities, a high level of physical fitness and ability to work.

The high level of motivation students have, they are distinguished by deep awareness of necessity and needs of physical exercises, sport, new fitness technologies, the availability of goals and definite practical ways to achieve it. For students with an average level, there is a sense of responsibility, interests, motives and needs for physical exercises and fitness techniques, but the attitude to physical education and health classes is worse than that of students with a high level. Students with a low level of motivation are aware of the importance of physical exercises and sport in life, but are characterized by a small number of positive motives; there is a lack of interest and desire for this kind of activity, frequent shyness at a very low physical development and physical fitness. Implementation of the methodical system of fitness technologies application in 
Table 4. The dynamics of male students' physical fitness during the pedagogical experiment (EG, $n=47 ; C G, n=41)$

\begin{tabular}{|c|c|c|c|c|c|c|}
\hline \multirow[t]{2}{*}{ Physical training tests } & \multirow[t]{2}{*}{ Groups } & \multirow{2}{*}{$\begin{array}{c}\begin{array}{c}\text { Before the } \\
\text { experiment }\end{array} \\
\mathrm{X} \pm \mathrm{m}\end{array}$} & \multirow{2}{*}{$\begin{array}{c}\begin{array}{c}\text { After the } \\
\text { experiment }\end{array} \\
\mathrm{X} \pm \mathrm{m}\end{array}$} & \multirow{2}{*}{$\begin{array}{c}\begin{array}{c}\text { Changes } \\
\text { after } 2 \text { years }\end{array} \\
\text { DX }\end{array}$} & \multicolumn{2}{|c|}{ Difference reliability } \\
\hline & & & & & $\mathbf{t}$ & $\mathbf{p}$ \\
\hline \multirow{2}{*}{ Running at $100 \mathrm{~m}(\mathrm{sec})$} & EG & $14.52 \pm 0.71$ & $13.68 \pm 0.83$ & 0.84 & 2.71 & $<0.01$ \\
\hline & CG & $14.48 \pm 0.64$ & $14.24 \pm 0.69$ & 0.24 & 1.37 & $>0.05$ \\
\hline \multirow{2}{*}{$\begin{array}{c}\text { Running at } \\
3000 \mathrm{~m} \text { (min, sec) }\end{array}$} & EG & $14.38 .4 \pm 0.19$ & $13.05 .8 \pm 1.92$ & 1.32 .6 & 3.62 & $<0.001$ \\
\hline & CG & $14.40 .6 \pm 2.25$ & $14.07 .1 \pm 2.18$ & 0.33 .5 & 1.84 & $>0.05$ \\
\hline \multirow{2}{*}{$\begin{array}{l}\text { Pull-ups on the crossbar } \\
\text { (times) }\end{array}$} & EG & $7.11 \pm 0.47$ & $13.04 \pm 0.57$ & 5.93 & 3.83 & $<0.001$ \\
\hline & CG & $6.98 \pm 0.52$ & $9.13 \pm 0.62$ & 2.15 & 2.27 & $<0.05$ \\
\hline \multirow{2}{*}{$\begin{array}{l}\text { Bending of arms in lying } \\
\text { support (times) }\end{array}$} & EG & $27.31 \pm 1.31$ & $40.24 \pm 1.07$ & 12.93 & 3.79 & $<0.001$ \\
\hline & CG & $28.14 \pm 1.28$ & $32.67 \pm 1.53$ & 4.53 & 1.91 & $>0.05$ \\
\hline \multirow{2}{*}{ Standing long jump (cm) } & EG & $211.47 \pm 2.42$ & $237.86 \pm 2.38$ & 26.39 & 2.32 & $<0.05$ \\
\hline & CG & $210.04 \pm 2.56$ & $216.43 \pm 2.61$ & 6.39 & 1.46 & $>0.05$ \\
\hline \multirow{2}{*}{ Sit-ups for 1 min (times) } & EG & $28.14 \pm 1.34$ & $42.64 \pm 1.47$ & 14.50 & 3.67 & $<0.001$ \\
\hline & CG & $28.02 \pm 1.38$ & $35.89 \pm 1.43$ & 7.87 & 2.12 & $<0.05$ \\
\hline \multirow{2}{*}{$\begin{array}{c}\text { Shuttle running } \\
4 \times 9 \text { (sec) }\end{array}$} & EG & $10.43 \pm 0.58$ & $8.73 \pm 0.67$ & 1.70 & 2.74 & $<0.01$ \\
\hline & CG & $10.74 \pm 0.63$ & $9.81 \pm 0.72$ & 0.93 & 2.14 & $<0.05$ \\
\hline \multirow{2}{*}{ Forward reach $(\mathrm{cm})$} & EG & $8.85 \pm 0.67$ & $16.22 \pm 0.46$ & 7.37 & 3.75 & $<0.001$ \\
\hline & CG & $9.18 \pm 0.64$ & $13.57 \pm 0.57$ & 4.39 & 2.71 & $<0.01$ \\
\hline \multirow{2}{*}{ Swimming (m) } & EG & $72.4 \pm 1.97$ & $96.7 \pm 2.01$ & 24.30 & 3.61 & $<0.001$ \\
\hline & CG & $73.7 \pm 1.88$ & $77.1 \pm 1.93$ & 3.40 & 1.28 & $>0.05$ \\
\hline
\end{tabular}

Table 5. The dynamics of female students' physical fitness during the pedagogical experiment (EG, $n=71 ; C G, n=73)$

\begin{tabular}{|c|c|c|c|c|c|c|}
\hline \multirow{2}{*}{ Physical training tests } & \multirow{2}{*}{ Groups } & \multirow{2}{*}{$\begin{array}{c}\begin{array}{c}\text { Before the } \\
\text { experiment }\end{array} \\
\mathrm{X} \pm \mathrm{m}\end{array}$} & \multirow{2}{*}{$\begin{array}{c}\begin{array}{c}\text { After the } \\
\text { experiment }\end{array} \\
\mathbf{X} \pm \mathbf{m} \\
\end{array}$} & \multirow{2}{*}{$\begin{array}{c}\text { Changes } \\
\text { after } 2 \\
\text { years }\end{array}$} & \multicolumn{2}{|c|}{ Difference reliability } \\
\hline & & & & & $\mathbf{t}$ & $\mathbf{p}$ \\
\hline \multirow{2}{*}{ Running at $100 \mathrm{~m}$ (sec) } & EG & $18.22 \pm 0.49$ & $17.11 \pm 0.43$ & 1.11 & 2.03 & $<0.05$ \\
\hline & CG & $18.16 \pm 0.38$ & $17.96 \pm 0.41$ & 0.20 & 1.34 & $>0.05$ \\
\hline \multirow{2}{*}{ Running at $2000 \mathrm{~m}$ (min, sec) } & EG & $11.58 .4 \pm 1.28$ & $10.37 .2 \pm 1.29$ & 1.21 .2 & 2.95 & $<0.01$ \\
\hline & CG & $11.37 .6 \pm 1.14$ & $11.22 .4 \pm 1.38$ & 17.2 & 1.67 & $>0.05$ \\
\hline \multirow{2}{*}{$\begin{array}{l}\text { Hanging with bending arms } \\
\qquad(\mathrm{sec})\end{array}$} & EG & $5.73 \pm 1.67$ & $13.22 \pm 1.54$ & 7.49 & 3.52 & $<0.001$ \\
\hline & CG & $5.21 \pm 1.51$ & $8.14 \pm 1.46$ & 2.93 & 1.98 & $<0.05$ \\
\hline \multirow{2}{*}{$\begin{array}{l}\text { Bending of arms in lying } \\
\text { support (times) }\end{array}$} & EG & $8.49 \pm 0.84$ & $16.29 \pm 1.27$ & 7.8 & 3.96 & $<0.001$ \\
\hline & CG & $8.75 \pm 0.81$ & $12.64 \pm 1.03$ & 3.89 & 2.78 & $<0.01$ \\
\hline \multirow{2}{*}{ Standing long jump (cm) } & EG & $163.57 \pm 2.69$ & $176.82 \pm 2.78$ & 13.25 & 2.13 & $<0.05$ \\
\hline & CG & $164.11 \pm 2.62$ & $169.58 \pm 2.73$ & 5.47 & 1.64 & $>0.05$ \\
\hline \multirow{2}{*}{ Sit-ups for 1 min (times) } & EG & $26.78 \pm 0.77$ & $39.57 \pm 1.19$ & 12.79 & 3.78 & $<0.001$ \\
\hline & $\mathrm{CG}$ & $27.24 \pm 0.86$ & $32.41 \pm 1.23$ & 5.17 & 2.36 & $<0.05$ \\
\hline \multirow{2}{*}{$\begin{array}{l}\text { Shuttle running } \\
4 \times 9 \mathrm{~m}(\mathrm{sec})\end{array}$} & EG & $11.06 \pm 0.64$ & $10.23 \pm 0.61$ & 0.83 & 2.07 & $<0.05$ \\
\hline & CG & $10.98 \pm 0.61$ & $10.83 \pm 0.68$ & 0.15 & 1.36 & $>0.05$ \\
\hline \multirow{2}{*}{ Forward reach $(\mathrm{cm})$} & EG & $11.94 \pm 0.53$ & $18.56 \pm 1.34$ & 6.62 & 4.13 & $<0.001$ \\
\hline & CG & $11.81 \pm 0.49$ & $13.73 \pm 0.94$ & 1.92 & 1.54 & $>0.05$ \\
\hline \multirow{2}{*}{ Swimming (m) } & EG & $64.3 \pm 1.75$ & $81.5 \pm 2.43$ & 17.20 & 3.62 & $<0.001$ \\
\hline & CG & $63.7 \pm 1.69$ & $67.2 \pm 1.76$ & 3.50 & 1.28 & $>0.05$ \\
\hline
\end{tabular}


Table 6. The dynamics of students' health level according to the "Health self-esteem" methodology during the pedagogical experiment $(\mathrm{n}=232, \mathrm{X} \pm \mathrm{m}$, in points)

\begin{tabular}{|c|c|c|c|c|c|c|c|}
\hline \multirow{2}{*}{ Gender } & \multirow{2}{*}{ Groups } & \multirow{2}{*}{$\mathbf{n}$} & \multirow{2}{*}{$\begin{array}{c}\begin{array}{c}\text { Before the } \\
\text { experiment }\end{array} \\
\mathrm{X} \pm \mathrm{m}\end{array}$} & \multirow{2}{*}{$\begin{array}{c}\begin{array}{c}\text { After the } \\
\text { experiment }\end{array} \\
\mathrm{X} \pm \mathrm{m}\end{array}$} & \multirow{2}{*}{$\begin{array}{c}\begin{array}{c}\text { Changes after } 2 \\
\text { years }\end{array} \\
\text { DX }\end{array}$} & \multicolumn{2}{|c|}{ Difference reliability } \\
\hline & & & & & & $\mathbf{t}$ & p \\
\hline \multirow{2}{*}{ Male } & EG & 47 & $15.16 \pm 1.23$ & $7.04 \pm 1.09$ & 8.12 & 4.94 & $<0.001$ \\
\hline & CG & 41 & $14.93 \pm 1.36$ & $11.38 \pm 1.32$ & 5.55 & 1.87 & $>0.05$ \\
\hline \multirow{2}{*}{ Female } & EG & 71 & $14.70 \pm 1.29$ & $6.91 \pm 1.20$ & 7.79 & 4.42 & $<0.001$ \\
\hline & CG & 73 & $14.62 \pm 1.32$ & $10.67 \pm 1.27$ & 6.15 & 1.99 & $>0.05$ \\
\hline
\end{tabular}

the educational process of students of experimental groups radically changed their attitude to physical activity, sport and new fitness technologies, contributed to the formation of motivation for physical and health improving, and sports activities.

The research of the dynamics of the formation of motivation for physical exercises and healthy lifestyle after the implementation of the methodical system of fitness technology application in the educational process of physical education showed a significant increase in students of EG that have high level of motivation: in males from $4.3 \%$ to $38.3 \%$, in females from $5.6 \%$ to $29.6 \%$. Similarly, the number of students increased with an average level of motivation in EG: in males from $17.1 \%$ to $48.9 \%$, in females $26.8 \%$ and $47.9 \%$ respectively. At the same time, there was a significant reduction in the number of students with a low level of motivation in EG: from $78.7 \%$ to $12.8 \%$ for males, and for females - from $67.6 \%$ to $22.5 \%$. At the same time, in the CG students trained according to the traditional system of physical education, there was no significant improvement in the motivation of either males or females (Table 3 ).

The obtained data suggest that the motivation for physical education classes that are conducted according to the new methodical system of fitness technologies application can be successfully formed during educational and upbringing activities.

An important condition for the implementation of a methodical system of fitness technologies application is to increase the level of general physical fitness of students and the development of their individual physical qualities that are important for life and increase productivity in future professional activities. Implementation of the methodological system into the educational process of students from the EG presupposed the coverage of theoretical and methodological information in the practical section, providing students with theoretical knowledge about mastering fitness techniques, methods and ways of fitness technology application both during the training and independent classes.

By choosing general training exercises, methods and techniques of their mastering, we took into account that the general physical training of students should ensure both harmonious and spiritual development of the students' personality. The content of general physical training reflects the peculiarities of the selected types of fitness technologies. At the initial stage of training, we developed the skills and abilities of the students from those fitness technologies that best met the students' needs. At the same time, at the initial level of education, the students became familiar with the basic, most available fitness technologies, received some knowledge about the content and the stages of the performed motor actions. Subsequently, the student had to perform certain motor actions independently and master the algorithm of their performing. Taking into account the motivation to fitness techniques classes, gender, age, level of health, physical fitness of students, etc., led to the correct choice of methods and means of training. In accordance with these factors, the planning of the methodology components was carried out: the total number of exercises at each stage of the training, the duration of exercises, the intervals for rest between the exercises, the types and nature of rest, the number of approaches and repetitions of each exercise, the intensity of exercises, etc. The practical section of fitness technologies application is a systematic, organized joint and two-way activity of the physical education instructor and students, aimed at the conscious, strong and deep mastering of special knowledge, skills and abilities by students, the process during which the student's personality is harmoniously and spiritually developing, the students' outlook on their future life is formed. This unit solved the development tasks: health improvement, physical training, physical development, mastering of physical and health improving, sports skills and abilities, etc.

The analysis of indicators of students' physical fitness obtained during the pedagogical experiment convincingly showed the high efficiency of implementation of the methodical system of fitness technologies application into physical education of students. In all of the nine tests that were completed to assess the level of physical fitness, EG students significantly improved their indicators (Table 4). The best indicators of physical fitness were shown by male students at $3000 \mathrm{~m}$ running at the end experiment, where the growth was $1 \mathrm{~min} 32.6 \mathrm{sec}(\mathrm{p}<0.001)$, in pull-ups on the crossbar (growth -5.93 times, $p<0.001$ ), bending and unbending of the arms in the lying support (growth -12.93 times; $\mathrm{p}<0.001$ ); sit-ups for $1 \mathrm{~min}$ (growth - 14.5 times; $\mathrm{p}<0.001$ ); forward reach (growth $-7.37 \mathrm{~cm} ; \mathrm{p}<0.001$ ), swimming (growth $-24.3 \mathrm{~m} ; \mathrm{p}<0.001$ ). Significant improvement of the indicators also took place at a $100 \mathrm{~m}$ running, in standing long jump, shuttle running of $4 \times 9$ 
$\mathrm{m}(\mathrm{p}<0.05-0.01)$. At the same time, the results of the CG were reliably improved only in pull-ups on the crossbar, situps, shuttle running $4 \times 9 \mathrm{~m}$, forward reach ( $<<0.05-0.01$ ). Such important tests as running at $3000 \mathrm{~m}$, bending and unbending of arms in lying support, standing long jump, swimming did not have significant improvement $(\mathrm{p}>0.05)$. This testifies that the traditional system of physical education does not provide the necessary level of physical fitness of students during two academic years.

In the female students from EG, the indicators of all physical fitness tests have also significantly improved (Table 5). The best results were achieved in the hanging with bending arms (growth -7.49 sec; $p<0.001$ ), bending and unbending of arms in lying support (growth -7.8 times; $\mathrm{p}<0.001$ ), sit-ups (growth -12.79 times; $\mathrm{p}<0.001$ ), forward reach (growth $-6.62 \mathrm{~cm}, \mathrm{p}<0.001$ ) and swimming (growth $-17.20 \mathrm{~m} ; \mathrm{p}<0.001$ ). Significant improvement of the results also occurred in the completion of other tests $(\mathrm{p}<0.05-0.01)$. In the CC, a significant improvement in the results of the female students took place in only four tests: hanging with bending arms, bending and unbending of arms in lying support, sit-ups and swimming ( $\mathrm{p}<0.05-$ $0.01)$. In other tests, there was no significant improvement in results $(p>0.05)$. The low levels of physical fitness are accompanied by uncertainty in their actions, depression, adaptation discomfort, deterioration of recovery processes during physical and mental load, it affects negatively on the livelihoods of students. Comparison of the results of the physical training test in EG and CG in both males and females students before the experiment showed that there was no significant difference between the groups ( $p>0.05)$. After conducting an experiment between males and females students in EG and CG, significant discrepancies were found which are within $(\mathrm{p}<0.05-0.001)$.

The analysis of the results of self-assessment of students' own health by the method of Professor V. P. Voytenko showed that at the beginning of the experiment the indicators of students of both males and females did not differ significantly ( $p>0.05)$. At the same time, the health level of students in all study groups was rated as "satisfactory". During the period of the pedagogical experiment, there was an improvement in the level of health among students of all groups (Table 6). But in the experimental groups (both males and females) the difference between the initial and final data is significant ( $\mathrm{p}<0.001)$, then in the control groups it is not reliable ( $\mathrm{p}>0.05)$.

Thus, in the male students of EG the level of health significantly improved by 8.12 points, in female students of EG - by 7.79 points $(p<0.001)$, and in males of CG - by 5.55 points, in females of $C G$ - by 6.15 points $(p>0.05)$. At the same time, at the end of the experiment, the level of health of students who were trained according to the authors' methodical system of fitness technologies application is significantly $(\mathrm{p}<0.05)$ better than that of students who were trained according to the traditional system of physical education in higher pedagogical education establishments, by 4.34 points in males and by 3.67 points in females. The health level of students of EG (both males and females) at the end of the experiment is rated as "good", but the health level of students of CG - as "average".This further emphasizes the high efficiency of the authors' methodical system of modern fitness technologies application in physical education of students.

\section{DISCUSSION}

The indicators of dynamics of students' physical fitness during the pedagogical experiment show clear enough criteria for evaluation. This is the state of the educational process on physical education, the level of development of physical qualities, the adequacy of the tools and methods used in the implementation of the methodical system of fitness technology application in the educational process on physical education and physical and health improving activities. The obtained indicators of students' physical fitness and health in EG both males and females at the end of the experiment confirm the fact that training according to the methodical system of fitness technology application combines a set of systematic means, techniques, rules and methods, pedagogical technologies, with the help of which the students realize, perform and practice motor actions which are aimed at increasing motor activity and involving them into physical and health improving activities. The obtained results confirm the conclusions of many scientists' works $[6,8,18,20,23,24,30,31]$ who studied the effect of physical activity and sport on performance indicators, health and efficiency of training and future professional activities.

The study of issues related to the implementation of the methodical system of fitness technologies application in the educational process on physical education of students showed the necessary to keep to the basic didactic and methodological regulations and principles, patterns of teaching motor activities; it is necessary to take into account the age, gender and individual characteristics of students when applying fitness technology; physical load must meet the peculiarities of physical health, physical development; systematically conduct pedagogical observation of the exercises performing technique, physical load and the health of students; each fitness technology class should form positive emotions and satisfaction for students.

\section{CONCLUSIONS}

1. The traditional system of physical education does not ensure the effective mastering of knowledge in the field of fitness technologies, in the field of physical culture and sport, it does not contribute to the formation of interests and motives for physical and health improving activities and increase of the level of physical activity during student training and future professional activity and viability.

2. The methodical system of fitness technologies application in the educational process of physical education significantly improves the level of motor activity, the- 
oretical training of students on physical education and motivation to a healthy lifestyle. The obtained theoretical knowledge will allow the students of experimental groups to deal with the matters of physical culture and sport, be able to apply them during independent exercises, self-improvement, organization of a healthy way of life, leisure activities, etc.

3. The positive influence of classes according to the authors' methodical system of fitness technologies application in the educational process of physical education in pedagogical establishments of higher education on the level of students' physical fitness of different genders is established. All the tests completed by the students of the EG show a significant $(\mathrm{p}<0.05-0.001)$ growth in the results, on the contrary in CG there was a significant difference between the indicators at the beginning and end of the experiment only in some tests. At the end of the research, EG students (both males and females) had significantly better results in all exercises who took part in tests than in CG ( $\mathrm{p}<0.05-0.001)$; it confirms the positive influence of training according to the modern fitness techniques.

4. Positive influence of training classes of the authors' methodical system on the students' health level was revealed - in the experimental groups the health level according to the method "Health self-esteem" significantly $(\mathrm{p}<0.001)$ improved during the experiment in males by 8.12 points, and in females - by 7.79 points; in control groups - has not been changed significantly.

5. Implementation of the methodical system of fitness technologies application in the educational process of physical education confirmed that physical education in higher pedagogical education establishments significantly activates the educational process, supports the high capability to work of students during the working day, promotes the activation of mental processes, etc.

Mastering a certain system of knowledge, skills and abilities of fitness technology application can attract more students to a healthy lifestyle, sport, better prepare for future professional activities, expand the scientific and cognitive potential, and provide long-term health and capability to work.

\section{REFERENCES}

1. Bolotin A., Bakayev V. Structure and content of the educational technology of managing students' healthy lifestyle. Journal of Physical Education and Sport. 2015; 15(3): 362-364. doi:10.7752/ jpes.2015.03054.

2. Kachan 0. A. Vprovadzhennja innovacijnykh tekhnologhij u fizychne ozdorovlennja ta sportyvnu dijaljnistj navchaljnykh zakladiv [Implementation of innovative technologies in physical health improving and sport activities of educational institutions]. Slavyansk: Vitoki; 2017, 138 p. (In Ukrainian).

3. Radas J., SesarV., Furjan-Mandic G. Differences between female subjects practicing Pilates and aerobics. Sport Mont. 2017; 15(3): 25-28. doi:10.26773/smj.2017.10.004.

4. Leuciuc F. Perception on physical education among students. Revista Romaneasca pentru Educatie Multidimensionala. 2018; 10(2): 134-143. doi:https://doi.org/10.18662/rrem/51.
5. Ilnytska G., KozinaZh., Kabatska 0. etal. Impact of the combined use of healthimproving fitness methods ("Pilates"and "Bodyflex") on thelevel offunctional and psychophysiological capabilities ofstudents. Journal of Physical Education and Sport. 2016; 16(1):234-240. doi:10.7752/jpes.2016.01037.

6. Pacesova P., Smela P., Kracek S. et al. Women's well-being, state and trait anxiety regarding their sport activity. Sport Mont. 2018; 16(2): 33-38. doi: $10.26773 /$ smj. 180606.

7. Batilani T. G., Belem I. C., Both J. Different profiles in terms of motivation and concerns of physical education students. Movimento. 2018; 24(2): 619-632. doi:10.22456/1982-8918.74947.

8. Cucui A. I. Study on sports activities in the free time of gymnasium cycle students. Revista Romaneasca pentru Educatie Multidimensionala. 2018; 10(4): 82-91. doi:https://doi.org/10.18662/rrem/74.

9. Zelenskyi B., Zelenskyi R. Motivation: attitude of students of higher education institutions of the I-II accreditation levels toward physical education classes. Theory and Methods of Physical Education. 2018; 18(3); 114-125. doi:10.17309/tmfv.2018.3.02.

10. Cybulska A., Drobnik P. An assessment of the impact of special training of inspiratory muscles in a fitness classes program on physical capacity of 20-25-year-old women. Baltic Journal of Health and Physical Activity. 2015; 7(4):37-47. doi:10.29359/BJHPA.07.4.04.

11. Griban G., Prontenko K., Zhamardiy V. et al. Professional stages of a physical education teacher as determined using fitness technologies. Journal of Physical Education and Sport. 2018; 18(2): 565-569. doi:10.7752/jpes.2018.02082.

12. Usatova I. A., Tsapodoi S. V. Suchasni tekhnologhiji fitnesu jak zasib vykonannja zavdanj fizychnogho vykhovannja dlja studentiv z porushennjam stanu zdorov'ja [Modern fitness technologies as means of performing physical education tasks for students with a disorderly health condition]. Cherkasy: ChNU; 2014, 88 p. (In Ukrainian).

13. Hawley E. T., Franks D. B. Ozdorovchyj fitnes [Health Fitness]. Kyiv: Olympic Literature; 2000, 367 p. (In Ukrainian).

14. Bulatova M. M., Usachov Yu. O. Suchasni fitnes-ozdorovchi tekhnologhiji u fizychnomu vykhovanni. Teorija ta metodyka fizychnogho vykhovannja [Modern fitness-health-improving technologies in physical education. Theory and methods of physical education]. Kyiv: Olympic Literature; 2008, 320 p. (In Ukrainian).

15. Mozolev 0., Bloshchynsky I., Alieksieiev 0. et al. Influence of modern fitness technologies on the state of health and development of motor abilities of 17-19-year-old female students. Journal of Physical Education and Sport. 2019; 19(Supplement issue 3): 917-924. doi:10.7752/jpes.2019.s3132.

16. Romanchuk 0., Bryskyn Yu., Sydorko 0. et al. Formation of pedagogical college students' readiness for sports and recreation activity. Physical Education and Sport.2015; 15(4):815-822. doi: 10.7752/jpes.2015.04125.

17. Nosko M., Arkhypov 0., Khudolii 0 . et al. Pedagogical conditions for swimming skills development in students of pedagogical educational institutions. Revista Romaneasca pentru Educatie Multidimensionala. 2019; 11(2): 240-255. doi:10.18662/rrem/127.

18. Warburton D., Nicol C. W., Bredin S. S. D. Health benefits of physical activity: the evidence. Canadian Medical Association Journal. 2006; 174: 801-809.

19. Zinchenko V. B., Usachov Yu. O. Fitnes-tekhnologhiji u fizychnomu vykhovanni [Fitness technologies in physical education]. Kyiv: NAU; 2011, 152 p. (In Ukrainian).

20. Mosur-Kaluza S., Guszkowska M. Physical activity and body image of women: literature review. Baltic Journal of Health and Physical Activity. 2015; 7(3): 29-37. doi:10.29359/BJHPA.07.3.04. 
21. Saeidi A., Tayebi S. M., Khosravi A. et al. Obesity, fat mass, osteopontin and exercise training. International Journal of Applied Exercises Physiology. 2019; 8(1): 177-179. https://doi.org/10.30472/ijaep. v8i1.372.

22. Kolokoltsev M., lermakov S., Prusik K. Motor skills and functional characteristics of students of different somatotypes. Physical Education of Students. 2018; 22(1): 31-37. doi:10.15561/20755279.2018.0105.

23. Rus C. M. Physical education and sports - a field more valuable and actual than ever. Editorial. Revista Romaneasca pentru Educatie Multidimensionala. 2017; 9(3): 7-9. doi:https://doi.org/10.18662/ rrem/2017.0903.01.

24. Tinazci C., Ealrefai S., Musa 0. Patterns of physical activity of Libyan undergraduate students at the university of Tripoli using international physical activity questionnaire (IPAQ). Sport Mont. 2019; 17(2): 103-106. doi 10.26773/smj.190618.

25. Kolokoltsev M. M., lermakov S. S., Jagiello M. Comparative analysis of the functional characteristics and motor qualities of students of different generations and body types. Pedagogics, Psychology, Medical-Biological Problems of Physical Training and Sports. 2018; 22(6): 287-295. doi:1 0.15561/18189172.2018.0602.

26. Zavydivska 0., Zavydivska N., Khanikiants 0. Self-management as a condition for creating a health culture among students. Journal of Physical Education and Sport. 2016; 16(1): 592-597. doi:10.7752/ jpes.2016.s1093.

27. Mozolev 0., Halus 0., Bloshchynskyi I. et al. Human resources management of educational development in sphere of physical culture and sports in Ukraine: comparative analysis (1992-2016). Journal of Physical Education and Sport. 2019; 19 (Supplement issue 1): 185-192. doi:10.7752/jpes.2019.s1028.

28. Griban G., Romanchuk S., Romanchuk V. et al. Physical preparation of students in Ukraine. American Journal of Scientific and Educational Research. 2014; 1(4): 286-291.

29. Prysiazhniuk S., Tolubko V., Oleniev D. et al. The influence of physical activities on biological age parameters of the first-year female students from the special medical department. Journal of Physical Education and Sport. 2018; 18(2):561-564. doi:10.7752/jpes.2018.02081.

30. Kharchenko 0., Kharchenko N., Shaparenko I. et al. Analysis of the physical development of youth and the state of its health. Wiad Lek. 2019; 72(4): 575-578.

31. Bulych E. Gh., Muravov Y. V. Zdorovj'e cheloveka: Byologhycheskaja osnova zhyznedejateljnosty y dvyghateljnaja aktyvnostj v ee stymuljacyy [Human health: the biological basis of vital activity and motor activity in its stimulation]. Kyev: Olympyjskaja lyteratura; 2002, 424 p. (In Russian).
32. Gruzieva T., Galiienko L., Pelo I. et al. Health and lifestyle of students youth: status, problems and ways of solution. Wiad Lek. 2018; 71(9):1753-1758.

The investigation is conducted under the topic of the research activity of the department of physical education of Zhytomyr Ivan Franko State University in 2014-2024 "Theoretical and methodological foundations of improving the educational process of physical education in higher education institutions» (state registration number 0114U003978).

\section{ORCID and contributionship:}

Valeriy O. Zhamardiy - 0000-0002-3579-6112 ${ }^{A, C}$

Olena M. Shkola - 0000-0003-3013-0423 ${ }^{B}$

Ivan M. Okhrimenko - 0000-0002-8813-5107 ${ }^{E}$

Oksana G. Strelchenko - 0000-0001-5965-9764 ${ }^{B}$

Alla I. Aloshyna - 0000-0001-6517-1984 C,F

Fyodor H. Opanasiuk - 0000-0003-3006-0664 ${ }^{D}$

Grygoriy P. Griban - 0000-0002-9049-1485 E

Vitalii P. Yahodzinskyi - 0000-0002-2874-180X ${ }^{\mathrm{C}}$

Oleksandr M. Mozolev - 0000-0002-3677-4433 ${ }^{\mathrm{F}}$

Kostiantyn V. Prontenko - 0000-0002-0588-8753 A,D

\section{Conflicts of interest:}

Authors declare no conflict of interest.

\section{CORRESPONDING AUTHOR Kostiantyn V. Prontenko}

Department of Physical Education, Special Physical Training and Sport, S. P. Koroliov Zhytomyr Military Institute, Zhytomyr, Ukraine tel: +380675069142

e-mail: prontenko-kostya@ukr.net

Received: 11.06 .2019

Accepted: 25.11.2019

A - Work concept and design, B - Data collection and analysis, $\mathbf{C}$ - Responsibility for statistical analysis, $\mathbf{D}$-Writing the article, $\mathbf{E}$-Critical review, $\mathbf{F}$ - Final approval of the article 